\title{
Exploration on the Integration of Red Songs into the Innovation of Ideological and Political Education in Colleges and Universities
}

\author{
Lin $\mathrm{Qu}$ \\ Tianjin University of Finance and Economics \\ Tianjin, China 300222
}

\begin{abstract}
As the valuable wealth of the Communist Party of China, it has far-reaching and extensive influence, and is an important carrier of Ideological and political education in colleges and universities. This paper will analyze and study the red songs from the three aspects and they are respectively artistic features, educational function and inheritance application. In the meantime, the author aims to integrate its essence into the ideological and political education work in colleges and universities and innovate the way of ideological and political education in order to demonstrate the application value and promoting role of red songs in the ideological and political education of colleges and universities.
\end{abstract}

Keywords-red songs; ideological and political education; innovation

\section{INTRODUCTION}

The report of the nineteenth Congress of the Communist Party of China clearly stated that building a powerful country in education is a basic project for the great rejuvenation of the Chinese nation. China's colleges and universities shoulder the fundamental task of nurturing men of talent and ethics, so it is indispensable for them to strengthen ideological and political education and moral education, carry forward the socialist core value and educate the students to set up a correct view of history, national, state and culture to enhance the backbone, spirit and aspirations of the Chinese people. Red songs, as an important part of red culture, are indispensable educational contents in red education. Red songs contain rich content and essence of ideological and political education, and display with a kind of expressive form of artistic characteristics. Moreover, the music itself bears the function of cultivating people accompanied by its rapid and extensive spreading as well as its depth into people's heart. So, the red songs have strong ideological and political education guidance and practical character. The application and inheritance of them is an important way to enhance ideological and political education in colleges and universities.

\section{The CONNOTATION OF RED SONGS AND THEIR ARTISTIC FEATURES}

Red songs originated from the new-democratic revolution period in China. They refer to the songs that have been produced and circulated in various periods, such as revolution, construction, reform and opening, and other songs with positive energy, especially songs of singing the praise of the revolutionary spirit, the Party and the Motherland. Red songs are an important manifestation of red culture and an important carrier of the red spirit. It is an effective push to strengthen the ideological and political education of college students because of its rich artistic elements, which lead to vivid images, and more because of the bearing of history and faith, which making them last long. The lyrics are vivid, novel, positive, healthy, harmonious and beautiful. Because of the use of figures of analogy, metaphor, repetition, parallelism, exaggeration and other rhetorical devices in the creation of lyrics, the emotional expression of red songs is more wonderful, the feeling of the picture is more intense and the lyrics are deeply rooted in the hearts of the people. Their melodies unfold one by one with the development of story plots. Through the fast and slow relaxation of the rhythm, the high and low ring of the melody can transfer the different emotions expressed by each song so that they are able to touch the heart, be deeply rooted in the people's heart, and shake the hearts. In addition, they are good at stirring the heart as well as moving and educating people with emotion. Their forms of expression are often direct and they have clear idea what to love or hate and the stories they tell tend to be vivid and lifelike. The artistic features help to prompt them to spread and popularize widely.

\section{THE FOUNDATION OF THE INTEGRATION OF RED SONGS INTO THE IDEOLOGICAL AND POLITICAL EDUCATION IN COLLEGES AND UNIVERSITIES}

Red education is an important part of Ideological and political education, while red songs embody the essence of red education. Therefore, in the process of Ideological and political education in colleges and universities, the integration of red songs, which has a strong ideological and psychological guidance function, has important practical significance, and the interconnectivity between the two lays the foundation for their mutual application.

\section{A. Mass Character}

In terms of mass character, red songs come from the masses and spread among the masses, They are inner 
expressions of the masses to the party. Ideological and political education also follows the ideological line of "coming from the masses and going to the masses" and follows the purpose of "serving the people wholeheartedly". In combination with ideological and political education in colleges and universities, it means "from students, to students", "to serve the teachers and students wholeheartedly", so as to realize "all members educate people, educate people in all directions, educate people all over the whole process", and then improve the level and quality of ideological and political education in colleges and universities.

\section{B. Contemporaneity}

From the perspective of the times, red songs are the embodiment of the party's history. They sing different themes at different times, pointing out directions for people in different historical periods and leading people to change their ideological knowledge. The ideological and political education in colleges and universities also has distinct characteristics of the times. The form, content and carrier of education are constantly updated and evolved with the development and change of the students' subject and the object of the social environment, in order to ensure the timeliness of ideological and political education.

\section{Spirituality}

In terms of spirit, red songs are a dazzling gem in the treasure house of Chinese music. They are not only artistic and educational, but also guide people with a positive spirit, hardworking spirit, and arouse their patriotism, national pride and social sense of responsibility. This is the realistic goal of ideological and political education in colleges and universities.

\section{INNOVATIVE ADVANTAGES OF RED SONGS IN IDEOLOGICAL AND POLITICAL EDUCATION IN COLLEGES AND UNIVERSITIES}

Red songs are one of the most easily spread, most influential and easily popularized among all kinds of red classics, such as red movies, red books, red dance dramas, and red dramas. Because music education has the characteristics of "cultivate people deeply and enlighten people speedily", the use of red songs in ideological and political education in colleges and universities is bound to be able to moisten things without sounds, so that the ideological and political education of college students will be carried out more in-depth, extensive and comprehensive.

\section{A. Musical Function Advantage}

Red songs, as an art form of music, possess the functional advantages of music itself.

1) Educational function advantage: French writer Romain Rolland said, "music is like bread, which is an indispensable food in life."When we listen to a red song, perhaps we do not know its author, title, and background, but it does not prevent us from being attracted by the story it depicts, and does not prevent us from being shocked by the emotions it shows. Perhaps their lyrics are delicate and short, and perhaps the melody is repeated, but the emotion and feelings will still be deeply rooted in the hearts of the people. This is the unique feature of the red songs. For example, songs such as "Red Plum Chanting" and "Praise of Heroes" are designed for expressing the love for the party, the country, the people' $s$ army, and the love for hometown as well as the praise for the hero, the people, the family, the friendship, the love, and the enemy and the abhorrence, anger, and contempt for enemies and imperialism. Their lyrics show clear idea what to love or hate and their songs are powerful, which convey a positive attitude and high morale. The recurrence of the revolutionary spirit help to evoke the patriotism of the listener and the educational significance is obvious. Thus, it can be seen that the study of red songs is conducive to the cultivation of college students' ideological and moral cultivation, helping to shape the personality and character of college students and improve the ideological and political awareness of them. In a word, red songs are an effective channel for college students to accept positive and effective ideological and political education.

2) Emotional functional advantage: Red song is a kind of sound expression art. It inspires and nurture people's thoughts and emotions through non-semantic and non-visual sound waves, rhythms, melodies and beautiful lyrics. If there is no emotional basis, all ideological and political education will be empty, tasteless, and they will fail to be deeply rooted in the hearts of people, not to mention letting people think. So, it is impossible for them to afford to play the effect of ideological and political education. When listening to a song, in addition to admiring its beautiful melody, the root what it impresses us lies in resonance. When we listen to a song in silence, we hear a story, an emotion, and a kind of strength from it. And the story, emotion, strength are the vitality that its creator endows the song, and the rich ideological content the song shows. It is this vitality that allows us to feel the same feelings and emotions as we listen to the songs, and to resonate with our hearts so that our thoughts can be purified and sublimated.

3) Aesthetic function advantage: The aesthetic principle of music is that the creator expresses his own experience of beauty with the ups and downs of melody, the speed of rhythm, and so on, so as to create beauty, dedicate the beauty, spread the beauty and cultivate the aesthetic ability of the person with the beauty story and the beauty emotion. When we appreciate or sing a red song, we can't help being attracted by the story it tells, shocked by the emotion it expresses, shaking with its melody, and changing the mood with the rhythm. We are immersed in the songs, as if our thoughts have ceased to exist. We have devoted ourselves to the world of music, purify the mind and sublimate the mind, which is the aesthetic function of the red song to us.

The red song has a strong artistic appeal and artistic expression. Listening to the red song, which eulogizes the party, sings the motherland, eulogizes the people, and praises the things of truth, goodness, and beauty, enables the listeners to love the party, the nation, the life and all good things from the heart. Through this edification of aesthetic education, the 
listener will be ideologically enlightened and his understanding can be improved, his model can be found in practice so as to profound changes will take place in his thoughts, emotions, ideals, and pursuits, achieving special effects in his aesthetic education.

\section{B. Guiding Advantages of Ideological and Political Education}

Due to its own background and subject matter, Red Songs can display a strong ideological and political orientation, possessing various ideological and political-oriented educational advantages such as patriotism education, ideal and faith education, and carrying forward the national spirit.

1) Patriotism education: Patriotism education is an indispensable part of ideological and political education in colleges and universities. The red song records both the revolutionary history of our country and our party, and the characters, things, scenes, and deeds of each historical period. Accordingly, it expresses the sentiments, feelings, sincerity and moods of each stage. So, it is important in patriotism education for contemporary college students. Its own distinct revolutionary emotions can easily arouse listeners to cherish the memory of patriotic history and related heroes. In the form of music, it deeply conveys our country's excellent cultural tradition, revolutionary spirit and praises the great rivers and mountains of the motherland, greatly enhancing the patriotic enthusiasm, national self-respect and pride of the students.

2) Ideal and belief education: The education of ideals and beliefs is the core of ideological and political education in Colleges and universities. The red songs are full of deep red spirits, and in the form of music, they vividly and concretely show the life's guiding role of ideals and beliefs contained in the red spirit. They use the lively ideals and beliefs education to cultivate the university students' spirits and characters of making unremitting efforts to realize their ideals.

The songs, such as "good example of Lei Feng", "the man of our army", "nothing to say" and so on tells the belief that our army are loyal to the ideals and the serve our people with beautiful melody, and the musical notes reveal the sincere feelings of devoting to the party and the people always; "Step into the new era", "get into the Renaissance" and other melodious show up the main theme that since the reform and opening up, people have been, under the leadership of the Communist Party, firming their ideals and beliefs, seeking truth from facts, pioneering innovation with sinuous melody; songs, such as "heroic Anthem", "defending the Yellow River", "unity is strength", "we are the Communist Successors", and so on, show the ideal and belief of the Chinese people to move forward bravely in different periods. The songs, "our workers have strength", "I offer oil for the motherland", "the revolutionaries are always young", have shown the situation of self-reliance and hard work of the working people. The melody of the song is strong and powerful, showing the joy after labor and the pride that can contribute to the motherland. These red songs with epochal significance and ideals and beliefs show the spiritual character that contemporary college students need through vocal music. In the process of learning, singing and appreciating, college students can feel the power of ideal and belief education close to body and mind, so as to firm their beliefs, study hard, improve and exercise themselves, and finally realizing their own value.

3) Carry forward the national spirit: National spirit is the spiritual support and spiritual power for a nation to survive and develop. It embodies the root vein and soul of the national culture. As an important base for cultivating talents, it is particularly important for colleges and universities to educate the students on the national spirit. College students are charged with the mission of carrying forward and inheriting the national spirit.

The spirits of self-improvement, being sturdy, being active, striving for progress, perseverance have inspired the Chinese people in history to dare to fight, to fight hard, to be not afraid of sacrifice, and to forge ahead. Especially when the interests, and even the right to life of the country have suffered threats, the spirits can be more excited. During the revolutionary war, the Communist Party of China held high the great banner of Anti-Japanese, and in the process of establishing the united front of the Anti Japanese War, the spirit of Jinggangshan, the Long March, the spirit of Yanan and the Hongyan spirit were born; after the founding of new China, Lei Feng spirit and Jiao Yulu spirit were molded; during the period of reform and opening up, the comrades of the whole party should adhere to carrying forward the spirit of revolution and struggle, strict discipline and self sacrifice, the unselfishness and the spirit that other people first. At the same time, they should bear the spirit of overwhelming all enemies and all difficulties, and the spirit of the revolutionary optimism to eliminate the difficulties and strive for victory; the pioneering spirit, Kong Fansen spirit and the spirit of fighting against floods under the leadership of the third generation of our national leaders. The national spirit of these different periods has converged into a flow of realistic power.

Red songs are the epitome of national spirit in different historical periods, and also the concrete manifestation of carrying forward the national spirit. "The Yellow River ode", "the Red Army is not afraid of the expedition difficult", "the public servant praise" and other songs display the indomitable, selfless and fearless, struggling, selflessly dedicating national spirit from the different historical period and the different perspective. Not only the songs are vivid, but also their lyrics touch people's hearts and their feelings are thick and deep. Thus, learning and singing red songs can help college students to understand the national history, national spirit and national mission quickly and intuitively, and then, making them have somewhat feelings from inside to the outside to cultivate the sense of national pride and mission of the college students.

\section{PRACTICAL INNOVATION OF THE INTEGRATION OF RED SONGS INTO IDEOLOGICAL AND POLITICAL EDUCATION IN UNIVERSITIES AND COLLEGES}

College students are the future of the motherland and the hope of the nation. Carrying out the inheritance of red songs in colleges and universities is an inevitable requirement for improving the level of ideological and political education in colleges and universities. Innovation drives development. The 
inheritance of red songs not only means singing a red song, but should combine the red songs with ideological and political education in colleges and universities to realize the time value of them and improve the ideological and political literacy of college students by using red songs.

In order to see more clearly the practical effect of red songs applied to ideological and political education in colleges and universities, the following experiments have been done:

The students in the same class are divided into two groups, with the same number of students in each group to carry out questionnaire investigation of ideological and political education (all questions are subjective). The first group answer the questions in the context of playing a red song and the second group answer questions in a completely quiet background. After the questionnaire are retrieved, the author find out that by comparing the two groups: the questionnaires contents of the first group are significantly more abundant than those of the second group; the students in the first group develop more personal inner thoughts than the second group; the questionnaires in the first group are more emotional than those in the second group. From this, it can be seen that red songs have a good guiding and infiltration effect. Compared with traditional ideological and political education, it can more deeply, more meticulously and more widely touch students' inner thoughts and emotions, making it easier for students to accept this unique ideological and political education.

Through experiments, it is not difficult to see that the dissemination, vocalization, and transmission of red songs are very useful for promoting ideological and political education in colleges and universities. Therefore, it is necessary to open up a new front for ideological and political education and introduce red songs into the ideological and political education theory class, the second classroom, and social practice.

First of all, introducing the red song into the ideological and political education theory classroom not only makes the classroom teaching content vivid, but also help students have a comprehensive grasp of the history of the party, revolutionary history, revolutionary spirit, and moral cultivation and enables the four courses of ideological and political theory to integrate with each other, which assist the students to accept and study deeply ideological and political theories and enhance their ideological and political awareness.

Secondly, introducing red songs into the second classroom specifically means that uses red songs as the carrier to carry out various forms of party day, group day activities, community activities, and competition activities and encourage students to participate in these activities, and experience red songs at the event. The charisma fosters students' love for the party. More importantly, they should feel the charm of red songs in their activities as well as cultivate sentiments and foster the quality of their love for the party, the state, the society, the labor and the devotion.

\section{CONCLUSION}

In the end, red songs should be introduced into social practice, such as visiting the birthplace of red songs, integrating a red song into education aid courses, interviewing red song composers or songwriters, and shooting a MV for red songs. It is a matter of great significance to combine the inheritance of red songs with the practice of ideological and political education of college students and encourage the students to inherit and carry forward red songs by using heads and hands of their own.

\section{REFERENCES}

[1] Yu Qian.The Application of Red Songs in the Cultivation of Socialist Core Values[D].Jiangxi Normal University, 2016. 余倩. 红色歌曲在社 会主义核心价值观培育中的运用[D].江西师范大学,2016

[2] Jiang Jingwen. A Probe into the Practical Approaches to Upgrade College Students' Humanities Quality through Aesthetic Education of Music[J].Art Education,2016,(04):272-273. 蒋婧文. 音乐美育提升大 学生人文素质的实践路径探析[J]. 艺术教育,2016,(04):272-273.

[3] Jiang Feng, Li Xiaoli. The Psychological Guidance Function of Ideological and Political Education in Red Songs - - Taking Dabie Mountain Red Songs as an Example[J].Journal of China Three Gorges University(HUMANITIES AND SOCIAL SCIENCES EDITION),2012,(05):22-24+46. 江峰, 李小莉. 红色歌曲的思想政治教 育心理导向功能——以大别山红色歌谣为例 $[\mathrm{J}]$. 三峡大学学报(人文 社会科学版),2012,(05):22-24+46.

[4] Ma Xing. Research on the Function of Red Song's Patriotism Education[D].Southwestern University,2010. 马兴. 红歌的爱国主义教 育作用研究[D].西南大学, 2010 .

[5] Yang Na. Study on the Function and Role of Red Classic Songs Ideological and Political Education [D].Shanxi University of Finance and Economics,2008. 杨娜. 红色经典歌曲的思想政治教育功能与作 用研究[D].山西财经大学, 2008 .

[6] Wang Zaichang. On Music Aesthetic Education in Regular Colleges and Universities [J].Journal of Shangqiu Normal University,2005,(04):153154. 王在畅. 论普通高校的音乐审美教育 $[\mathrm{J}]$. 商丘师范学院学 报,2005,(04):153-154. 